\title{
HUBUNGAN POLA ASUH DENGAN KEJADIAN STUNTING PADA BALITA USIA 24-59 BULAN DI DESA MULIO REJO KEC. SUNGGAL
}

\author{
Urbanus Sihotang \\ Poltekkes Kemeskes Medan Jurusan Gizi \\ Email : urbanussihotang66@gmail.com
}

\begin{abstract}
Background: Stunting is a chronic condition of growth disruption which is described in the zscore of $T B / U<-2 S D$ due to inadequate nutrition during the growth mass Stunting in toddlers is a time that is prone to experiencing malnutrition problems, because toddlers' bodies experience relatively fast growth and development and will determine the quality of growth in the future

Objective: Knowing the Relationship between Parenting Pattern and the Incidence of Stunting in Toddlers Aged 24-59 Months in Mulio Rejo Village, Kec. Sunggal.

Methods: This study is an observational study with cross sectional study design. Respondents were 48 mothers who have toddlers aged 24-59 months were chosen by simple random sampling method. The data taken regarding feeding habits, parenting habits, hygiene habits, and habits of getting health services were obtained through questionnaires, and the incidence of child stunting obtained from measurements of children's height using a toddler's height measurement tool. Data analysis to observe the relationship between variables using the Chi-Square test.

Results: The results showed the proportion of toddler stunting in village Mulio Rejo was 20,8\%. There was no a significant correlation between feeding habits ( $p$-value $=1,000$ ) on the incidence of toddler's stunting

Conclusion : There was no correlation between mother's parenting habits, feeding habits, parenting habits, hygiene habits and health care habits with the incidence of stunting.
\end{abstract}

Keywords: parenting style, stunting, toddlers aged 24-59 months

\begin{abstract}
ABSTRAK
Latar Belakang : Stunting merupakan salah satu permasalahan status gizi pada balita yang digambarkan sebagai bentuk kegagalan pertumbuhan akibat gizi buruk dan kesehatan selama periode prenatal dan postnatal. Dampak stunting tidak hanya pada segi kesehatan tetapi juga mempengaruhi tingkat kecerdasan anak. Stunting akan berdampak dan dikaitkan dengan proses kembang otak yang terganggu, dimana dalam jangka pendek berpengaruh pada kemampuan kognitif. Dampak jangka panjang dapat mengurangi kapasitas untuk berpendidikan lebih baik dan hilangnya kesempatan untuk peluang kerja dengan pendapatan lebih baik.

Tujuan: Mengetahui Hubungan Pola Asuh Dengan Kejadian Stunting Pada Anak Balita Usia 2459 Bulan di Desa Mulio Rejo Kec. Sunggal.

Metode : :Penelitian ini merupakan penelitian observasional yang menggunakan dengan desain Cross Sectional. Responden adalah 48 orang ibu yang mempunyai balita usia 24-59 bulan dengan metode pengambilan sampel secara acak sederhana. Data yang diambil mengenai kebiasaan pemberian makan, kebiasaan pengasuhan, kebiasaan kebersihan, dan kebiasaan mendapatkan pelayanan kesehatan yang didapat melalui kuisioner, dan kejadian stunting anak yang didapat dari hasil pengukuran tinggi badan anak menggunakan alat ukur tinggi badan balita. Analisis data untuk melihat hubungan antara variabel menggunakan uji Chi-Square.

Hasil : Hasil penelitian menunjukkan prevalensi stunting sebesar 20,8\%. Tidak ada hubungan pola asuh ibu tentang kebiasaan pemberian makan, kebiasaan pengasuhan, kebiasaan kebersihan dan kebiasaan mendapatkan pelayanan kesehatan dengan kejadian stunting

Kesimpulan : Tidak ada hubungan yang signifikan antara pola asuh ibu dengan kejadian stunting di desa Mulio Rejo.
\end{abstract}

Kata Kunci : Pola Asuh, Stunting, Anak Balita Usia 24-59 Bulan 


\section{PENDAHULUAN}

Status Gizi merupakan keadaan tubuh seseorang yang diakibatkan oleh konsumsi, penyerapan (absorpsi), dan penggunaan zat gizi makanan dalam tubuh. Status gizi merupakan factor penting untuk menilai seseorang dalam keadaan sehat atau tidak menderita penyakit akibat gangguan gizi Ketidak seimbangan dalam penyediaan pangan menyebabkan masalah dalam pemenuhan gizi yakni masalah gizi kurang salah satunya adalah stunting. ${ }^{1}$

Stunting merupakan satu permasalahan status gizi pada balita yang digambarkan sebagai bentuk kegagalan pertumbuhan akibat gizi buruk dan kesehatan selama periode prenatal dan postnatal. ${ }^{2}$. Stunting ditandai dengan tinggi badan yang lebih pendek dibandingkan dengan anak seusianya. Anak yang menderita stunting akan lebih rentan terhadap penyakit dan ketika dewasa berisiko untuk mengidap penyakit degeneratif ${ }^{3}$. Stunting muncul sebagai akibat dari keadaan kekurangan gizi yang terakumulasi dalam waktu yang cukup lama sehingga akan lebih terlihat manifestnya secara fisik di usia $24-59$ bulan.

Dampak stunting akan mempengaruhi status kesehatan tingkat kecerdasan anak. Hubungan stunting dengan kecerdasan anak akan berdampak pada proses perkembangan otak yang terganggu, dimana dalam jangka pendek berpengaruh pada kemampuan kognitif. Dampak jangka panjang dapat mengurangi kapasitas untuk berpendidikan lebih baik dan hilangnya kesempatan untuk peluang kerja dengan pendapatan lebih baik ${ }^{4}$. Menurut data World Health Organization
(WHO) Indonesia termasuk Negara ketiga dengan prevalensi tertinggi di Regional Asia Tenggara yaitu $36,4 \%$ setelah Timor Leste $(50,2 \%)$ dan India $(38,2 \%)^{3}$ Hal ini menunjukkan pada tahun tersebut prevalensi stunting di Indonesia lebih tinggi daripada negara lain di Asia Tenggara, seperti Myanmar (35\%), Vietnam (23\%), dan Thailand (16\%). ${ }^{5}$ Telah banyak upaya yang dilakukan oleh pemerintah RI khususnya Kementerian Kesehatan untuk menurunkan angka stunting, hasilnya cukup menggembirakan. Dari 2 kali Riset Kesehatan Dasar (Riskesdas) terakhir yaitu 2013 dan 2018 telah terjadi penurunan angka stunting sebesar $6,4 \%$ yaitu dari $37,2 \%$ turun menjadi $30,8 \%$ dan diharapakan angka stunting dapat turun 3\% setiap tahun, sehingga target $19 \%$ pada tahun 2024 dapat tercapai. Meskipun persentasenya sudah turun tapi angka ini termasuk tinggi. Menurut standar World Health Organization (WHO), suatu wilayah dikatakan mengalami masalah gizi akut bila prevalensi bayi stunting lebih dari $20 \%$ atau balita kurus di atas 5\%.6 ${ }^{6}$ Sedangkan prevalensi stunting di Sumatera Utara hasil Riskesdas 2013 dan 2018 masih berada di bawah angka rata-rata nasional yaitu masing-masing $28,5 \%$ dan $32,4 \%{ }^{6}$. Hasil ini masih lebih tinggi dibandingkan rata-rata nasional. Demikian juga, prevalensi stunting di Kabupaten Deli Serdang masih termasuk kategori tinggi berdasarkan hasil pemantauan status gizi tahun 2018 sebesar $33,3 \%^{7}$ 

Pengasuhan merupakan faktor yang sangat erat kaitannya dengan pertumbuhan dan perkembangan anak berusia di bawah lima tahun. Pada masa ini anak masih benar-benar tergantung pada perawatan dan pengasuhan oleh ibunya. Dalam tumbuh kembang anak, peran ibu sangat dominan untuk mengasuh dan mendidik anak agar tumbuh dan berkembang menjadi anak yang berkualitas. Pola asuh ibu memiliki peran dalam kejadian stunting pada balita karena asupan makanan pada balita yang diatur oleh ibunya. Ibu yang pola asuh baik akan cenderung memiliki balita dengan status gizi yang lebih baik daripada ibu yang pola asuh kurang ${ }^{8}$.

Faktor pola asuh yang tidak baik dalam keluarga merupakan salah satu penyebab timbulnya permasalahan gizi. Pola asuh meliputi kemampuan keluarga untuk menyediakan waktu, perhatian dan dukungan dalam memenuhi kebutuhan fisik, mental dan sosial dari anak yang sedang tumbuh dalam keluarga 9. Menurut penelitian Rahmayana, dkk (2014) Pola asuh didalam keluarga berupa praktik pemberian makan, rangsangan psikososial, praktik kebersihan/hygiene, sanitasi lingkungan dan pemanfaatan pelayanan kesehatan mempunyai hubungan yang signifikan dengan kejadian stunting anak usia 24 - 59 bulan..$^{10}$

$$
\text { Penelitian-penelitian yang }
$$
berhubungan dengan pola asuh dengan kejadian stunting yaitu bahwa ada pengaruh pola pengasuhan dengan kejadian stunting, jika pengasuhan kurang baik maka lebih banyak anaknya stunting. ${ }^{11}$. Febriani ,dkk (2019) menyatakan pola asuh tentang pemberian makanan yang kurang baik $68,4 \%$ stunting, kebiasaan pengasuhan yang kurang baik $64,7 \%$ stunting dan kebiasaan kebersihan yang kurang baik 71,4\% stunting 13. Demikian juga, penelitian Hardianty (2019) yang menyatakan ada hubungan yang signifikan antara pola asuh dengan kejadian stunting. Dilihat dari segi usia kejadian stunting paling banyak terjadi pada usia 2459 bulan. $^{12}$

Hasil laporan pemantauan pertumbuhan balita bulan Januari tahun 2020 bahwa di wilayah kerja Puskesmas Mulio Rejo Kec. Sunggal balita pendek yang terbanyak terdapat di Desa Mulio Rejo yaitu 7 orang pendek dan kurus. Di daerah Desa Mulio Rejo Kec. Sunggal ini memiliki lingkungan yang kurang bersih dan cara mengasuh anak kurang baik dikarenakan yang merawat anak balitanya yaitu pengasuhnya. Sehingga, anak balita di daerah ini banyak mengalami kekurangan asupan nutrisi dengan baik.

Dari uraian diatas dilakukan penelitian yang bertujuan untuk menganalisis hubungan pola asuh berupa kebiasaan pemberian makan, kebiasaan pengasuhan, kebiasaan kebersihan dan kebiasaan mendapatkan pelayanan kesehatan dengan kejadian stunting balita di desa Mulio Rejo Kec. Sunggal.

\section{METODE PENELITIAN}

Penelitian ini merupakan observasional yang dilakukan menggunakan pendekatan kuantitatif dengan desain Cross Sectional yang dilakukan pada bulan 21-26 Mei 2020 2019 di di Desa Mulio Rejo Kec. Sunggal. Populasi seluruh Balita Usia 24-59 Bulan di Dusun XVIII Desa Mulio Rejo sejumlah 100 orang dan jumlah sampelnya dihitung 
menggunakan rumus Lemeshow.

Berdasarkan hasil perhitungan diperoleh jumlah sampel 48 orang dan teknik pengambilan sampel adalah secara acak sederhana. Data yang dikumpulkan adalah karakteristik anak dan responden, data pola asuh dan kejadian stunting balita. Data pola asuh dikumpulkan dengan wawancara dan kejadian stunting menggunakan indeks TB/U. Pengolahan data yang telah dikumpulkan diaktegorikan dengan varaibel pola asuh diaktegorikan menjadi baik, jika persentase skor $\geq 75 \%$ dan kurang baik, jika persentase skor $<75 \%$ sedangkan kejadian stunting dikategorikan menjadi stunting jika z-score $<-3 \mathrm{SD}$ s/d <-2 SD dan tidak stunting jika zscore $\geq-2$ SD. Analisis data menggunakan uji Chi-Square

\section{HASIL DAN PEMBAHASAN}

Lebih banyak responden berusia 30-39 tahun dan sebagian besar sudah dengan pendidikan menengah ke atas, dengan mayoritas ibu tidak bekerja/ ibu rumah tangga. (Tabel 1).

Tabel 1. Distribusi Responden Berdasarkan Umur Ibu
- Wiraswasta 7

- Petani 3

- PNS 2

- Ibu Rumah Tangga 32

- Guru 1

- Pegawai Swasta 3

Lebih banyak sampel berjenis kelamin lakilaki dan paling sedikit balita ada pada kategori umur 5 tahun dan kelompok umur yang lain hampir sama banyaknya (Tabel 2)

Tabel 2. Karakteristik Sampel

\begin{tabular}{cc}
\hline \multicolumn{1}{c}{ Variabel } & n \\
\hline Jenis Kelamin & \\
$-\quad$ Laki-laki & 26 \\
$-\quad$ Perempuan & 22 \\
\hline Umur (tahun) & \\
-2 & 11 \\
-3 & 18 \\
-4 & 17 \\
-5 & 2 \\
\hline
\end{tabular}

Pola asuh yang tidak baik, lebih banyak dibandingkan dengan pola asuh yang baik. Berdasarkan staus gizi dengan BB/U lebih besar termasuk kategori tidak stunting (Tabel 3)

Tabel 3. Distribusi karakteristik variabel penelitian

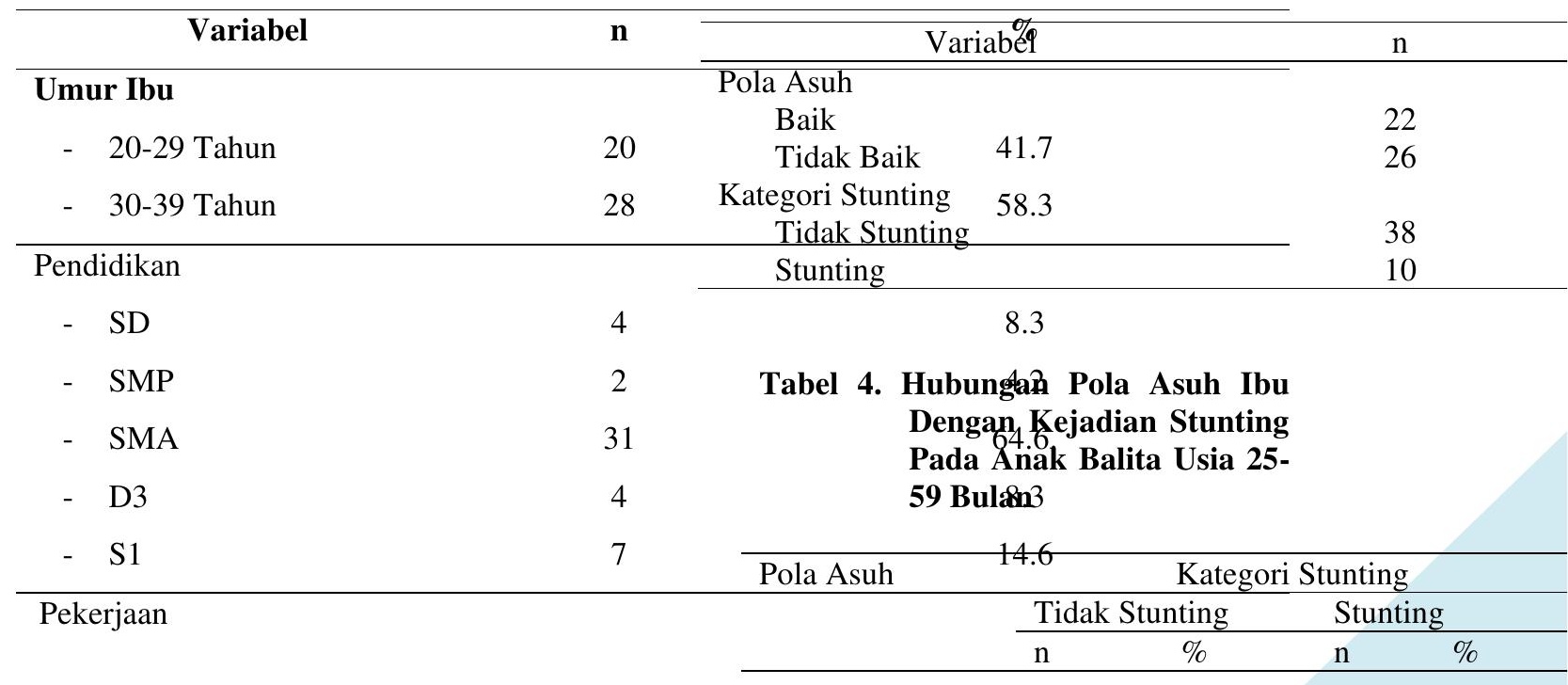




\begin{tabular}{|c|c|c|c|c|}
\hline Baik & 17 & 77,3 & 5 & dalab.7penurQ̨an stlonting sel,odio dengan \\
\hline Kurang Baik & 21 & 80,8 & 5 & 19,2 PPI 26,100 \\
\hline Jumlah & 38 & 79,2 & 10 & 20,8 \\
\hline
\end{tabular}

Pola asuh ibu antara anak stunting dan tidak stunting tidak berbeda secara signifikan. Sebagian besar pola asuh yang baik maupun yang kurang baik mempunyai anak stunting yang hampir sama banyaknya (Tabel 5)

\section{PEMBAHASAN}

\section{Kejadian Stunting}

Hasil penelitian menjelaskan dari 48 anak balita ada 10 orang $(20,8 \%)$ status gizi balita dengan indeks $\mathrm{BB} / \mathrm{U}$ menderita stunting yang terdiri dari sangat pendek $0 \%$ dan pendek 20,8\%. Sesuai gambaran prevalensi stunting di Indonesia, provinsi Sumatera Utara dan Sumatera Utara dan Kabupaten Deli Serdang berdasarkan Riskesdas 2018 yaitu sebesar masingmasing 30,8\%, 32,4\%. ${ }^{6}$ dan kabupaten $33,3 \%{ }^{7}$. Ini menunjukan prevalensi stunting di desa Mulyo Rejo khususnya lingkungan dusun XVIII lebih rendah dibandingkan prevalensi angka nasional, Sumatera Utara maupun kabupaten Deli Serdang. Tetapi, menurut WHO ini masih menjadi masalah kesehatan karena stunting harus dibawah $<20 \%$. Penelitian oleh Febriani, dkk (2019) menggambarkan prevalensi balita stunting di kota Palembang sebesar 29\%.13 Penelitian serupa di Kabupaten Pasaman Barat menyebutkan sebanyak $11 \%$ balita usia 2459 mengalami stunting ${ }^{14}$. Sedangkan penelitian Eka, dkk (2019) menyebutkan masalah gizi stunting pada balita di Lombok Tengah sebesar 39,5\% ${ }^{15}$. Penelitianpenelitian diatas mengindikasikan bahwa masih tingginya prevalensi stunting di Indonesia dan upaya yang terus dilakukan

\section{Pola Asuh}

Pola pengasuh adalah suatu interaksi antara otangtua dan anak dengan mengajarkan nilai atau norma, memberikan perhatian, menunjukkan sikap dan perilaku yang baik bagi anak. Sehingga, dengan pola pengasuhan yang baik, maka perkembangan anak juga akan baik. Proses pengasuhan ini erat berhubungan dengan kelekatan antara anak dengan orangtua dimana proses menimbulkan ikatan emosional secara timbal balik antara anak dengan pengasuh ${ }^{\mathbf{1 6}}$. Hasil penelitian menghasilkan kelompok pola asuh ibu yang baik terdapat $45,8 \%$, sedangkan kelompok pola asuh ibu yang kurang baik terdapat $54,2 \%$. Untuk menilai pola asuh ibu terhadap kejadian stunting peneliti menilainya menggunakan kuesioner yang terbagi jadi 4 kategori yaitu mengenai : Praktek pemberian makan, perawatan anak, kebersihan dan sanitasi lingkungan. Pola asuh yang dilakukan dengan baik terdapat pada pertanyaan pemberian praktek pemberian makan anak balita yaitu frekuensi anak balita telah diberikan makan 3 kali per hari dan memberikan makan pada anaknya pada saat pagi, siang dan malam. Perawatan anak telah sudah $100 \%$ menerima petugas kesehatan untuk datang kerumah untuk melakukan imunisasi. Ibu telah mencuci tangan dengan sabun sebesar 97,9\% sebelum memberikan makan anaknya. Sudah 100\% keluarga memiliki saluran pembuangan air dari kamar mandi, buang air besar sudah di toilet. Sedangkan pola asuh yang dilakukan 
tidak baik adalah tentang praktek pemberian makan bahwa hanya $35,4 \%$ ibu membatasi anaknya untuk melakukan jajan. Hanya 45,8\% ibu memantau jenis makanan yang dikosumsi anak termasuk jajanan dan pada sanitasi lingkungan masih terdapat $21 \%$ lantai rumah keluarga masih berlantai tanah atau kayu.

Menurut (Soetjiningsih, 2015) pada anak-anak yang mendapat asuhan yang baik dan pemberian makanan yang cukup dan bergizi, pertumbuhan fisik maupun selsel otaknya akan berlangsung dengan baik. Salah satu dampak dari pengasuhan yang tidak baik adalah anak sulit makan dan obesitas atau kelebihan berat badan juga berdampak kurang baik untuk anak. ${ }^{16}$ Pola pengasuhan merupakan hal yang penting dalam proses tumbuh kembang anak. Salah satu faktor yang mempengaruhi pertumbuhan dan perkembangan anak adalah adanya faktor psikososial yang didalamnya mencakup hal penting dalam kehidupan anak yaitu pentingnya stimulasi dalam pengasuhan. Pola pengasuhan yang baik merupakan gambaran adanya interaksi positif anak dengan pengasuh utama yang berperan dalam perkembangan emosi dan psikologis anak sehingga menciptakan tumbuh kembang anak yang normal. ${ }^{17}$

Hubungan Pola Asuh Ibu Dengan Kejadian Stunting Pada Anak Balita Usia 25-59 Bulan

Berdasarkan hasil analisis bivariat dengan uji chi square menunjukkan tidak ada hubungan yang signifikan antara pola asuh ibu dengan kejadian stunting balita usia $24-59$ bulan $(p=1,000>0,05)$. Penelitian ini sama dengan penelitian Ni'imah, dkk (2015) pada keluarga miskin di kabupaten Bojonegoro menyatakan bahwa tidak ada hubungan pola asuh ibu dengan stunting. Dimana pola asuh ibu yang tidak baik sama persentasenya mempunyai anak yang stunting yaitu $50 \%$ dengan pola asuh ibu yang baik. ${ }^{8}$ Penelitain yang sama oleh Murtini dan Jamaluddin di kabupaten Sidrap menyimpulkan tidak ada hubungan yang signifikan pola asuh dengan kejadian stunting. Penelitian ini menyimpulkan salah satu faktor penyebab stunting adalah berat badan lahir rendah. ${ }^{18 .}$ Penelitian yang sama oleh Ilya Krisnana (2020) di Jawa Timur bahwa tidak ada hubungan yang signifikan pola asuh ibu dengan kejadian stunting. Penelitian ini menyimpulkan bahwa faktor terjadinya insiden stunting adalah factor sosial (pendidikan) ${ }^{\mathbf{1 9}}$. Penelitian lain mendukung pernyataan ini bahwa faktor lain yang menyebabkan stunting adalah lama pendidikan, jika pendidikan ibu kurang dari 9 tahun merupakan faktor risiko penting terjadinya penurunan pertumbuhan linier pada anak usia kurang dari 2 tahun. ${ }^{20}$ Pola asuh dan status gizi sangat dipengaruhi oleh pemahaman ibu dalam mengatur kesehatan dan gizi dalam keluarganya. Oleh karena itu, diperlukan pendidikan untuk dapat mengubah perilaku yang mampu mengarah pada peningkatan gizi kesehatan pada ibu dan anak. ${ }^{19}$

Pola asuh ibu memiliki peran dalam kejadian stunting pada balita karena asupan makanan pada balita sepenuhnya diatur oleh ibunya. Ibu dengan pola asuh baik akan cenderung memiliki balita dengan status gizi yang lebih baik daripada ibu dengan pola 
asuh yang kurang. Namun penelitian Ni'mah, Cholifatun dan Lailatul Muniroh (2016) tidak ada hubungan yang signifikan antara pola asuh ibu dengan kejadian stunting. Pola asuh yang tidak baik belum tentu memiliki balita dengan masalah stunting yang lebih besar daripada ibu dengan pola asuh yang baik. Hal ini bisa jadi dikarenakan meskipun pola asuh ibu baik, terdapat keterbatasan dalam memenuhi kebutuhan sehari-hari sehingga pola asuh ibu tidak memengaruhi terjadinya masalah wasting dan stunting. ${ }^{8}$ Menurut Komalasari (2020) tidak adanya hubungan pola asuh dengan kejadian stunting dimungkinkan karena adanya factor lain yang lebih dominan yaitu: tingkat pendidikan ibu, riwayat pemberin ASI dan status gizi ibu 21 Sutarto (2018) menyatakan bahwa stunting disebabkan oleh factor yang multidimensional yang bukan hanya gizi buruk ibu saat mengalami kehamilan, namun juga disebabkan karena praktik pengasuhan yang kurang baik yang menyebabkan bayi tidak diberikan ASI ekslusif, kurang tepatnya pemberian MP ASI, kurang memanfaatkan pelayanan ${ }^{22}$

Hasil kajian literature review yang dilakukan Henny, dkk menunjukkan bahwa terdapat beragam prediktor stunting pada usia anak balita di Indonesia. Kajian literature ini menunjukkan bahwa berat badan lahir rendah, kelahiran prematur, orang tua bertubuh pendek, pendidikan orang tua, banyaknya anggota keluarga, terjadinya infeksi, dan proses menyusui secara signifikan berhubungan dengan stunting pada masa kanak-kanak. ${ }^{23}$. Temuan menunjukkan bahwa untuk mengurangi stunting di Indonesia perlunya mengembangkan promosi kesehatan terintegrasi, pencegahan dan intervensi. Pencegahan dan intervensi stunting intergratif harus menggunakan pendekatan multi sektoral yang melibatkan pelayanan kesehatan profesional, keluarga, pemerintah, dan masyarakat. Demikian juga hasil kajian Febri Wicaksono dan Titik Harsanti berdasarkan data Riset Kesehatan Dasar 2013 menemukan bahwa stunting disebabkan oleh interaksi yang sangat kompleks dari berbagai faktor yaitu tidak hanya berasal dari tingkat individu, tetapi juga di tingkat rumah tangga dan masyarakat . Kajian ini menjelaskan factor-faktor yang meningkatkan stunting pada anak-anak adalah jumlah anggota rumah tangga, anak yang tinggal di tempat kumuh, di pedesaan lebih tinggi stunting dibandingkan perkotaan, kemiskinan akan mempengaruhi gizi anak, dimana makanan yang dikonsumsi tidak mencukupi, meningkatnya penyakit infeksi dan kurangnya perawatan kesehatan dasar $^{24}$.

Penelitian di daerah Ethiopia Selatan menunjukkan bahwa faktor penentu stunting adalah pajanan penyakit diare, pajanan ISPA, keterlambatan inisiasi ASI setelah anak lahir, ASI pertama (kolostrum) dibuang, kurang vaksinasi, sumber makanan hewani yang kurang, dan sumber air minum yang tidak aman. ${ }^{25}$. Paparan diare berhubungan dengan kekurangan gizi. Ini mungkin karena kehilangan cairan dan elektrolit, kehilangan nafsu makan dan penyerapan di usus. ${ }^{26}$. Sampel yang mengalami ISPA 3 kali lebih mungkin mengalami kekurangan gizi dibandingkan 
dengan mereka yang tidak mengalamin ISPA. $^{27}$

Penelitian di Ethopia menyatakan bahwa inisiasi menyusui yang terlambat setelah satu jam setelah lahir memiliki hubungan yang signifikan dengan gizi kurang. Individu yang mulai menyusui setelah satu jam setelah kelahiran memiliki resiko 5 kali lebih besar mengalami stunting dibandingkan dengan anak yang mulai menyusui dalam waktu satu jam setelah lahir. Hal ini bisa jadi karena inisiasi dini mengakibatkan peningkatan produksi ASI. ${ }^{28}$ Penelitian di Ethopia Anak-anak yang keluarganya menggunakan air minum dari sumber yang tidak aman memiliki kemungkinan 7 kali lebih besar mengalami kekurangan gizi dibandingkan dengan mereka yang menggunakan sumber air yang aman. $^{29}$

Penelitian di Mexico menjelaskan berat badan lahir rendah dan perawakan ibu yang pendek, jumlah anak berusia $<5$ tahun lebih dari satu dalam satu keluarga dan penduduk asli menjadi faktor risiko tingkat individu terjadinya stunting. Berat badan lahir rendah yang biasanya disebabkan oleh intrauteri growth restriction (IUGR) atau pertumbuhan janin terhambat (PJT) sebelumnya telah diidentifikasi sebagai salah satu faktor risiko utama dengan beban stunting tertinggi 30 . Demikian juga penelitian Loida, dkk (2017) factor penyebab stunting adalah berat badan lahir, status pendidikan ibu, pekerjaan ibu, tinggal di pedesaan, jumlah anggota keluarga, jumlah balita dalam rumah tangga, memasak dengan arang, menempati rumah kayu atau jerami atau perumahan tanpa lantai yang layak, durasi menyusui, durasi pemberian ASI eksklusif, dan waktu mulai MP-ASI. ${ }^{31}$. Penelitian Garcia (2017) di Mozambik menyatakan faktor risiko stunting pada anak balita adalah jumlah anak usia $<5$ tahun lebih dari 1 orang dan rawan pangan sedang sampai berat. Para ahli telah menjelaskan bahwa jumlah yang lebih tinggi anak berusia $<5$ tahun per rumah tangga mungkin terkait dengan praktik menyusui yang kurang optimal di antara adik-adiknya, serta persaingan untuk makanan dan sumber daya lainnya, yang pada akhirnya dapat menyebabkan kekurangan gizi pada anak. ${ }^{32}$

\section{SIMPULAN DAN SARAN}

Pola asuh ibu tidak signifikan berbeda antara anak stunting dibandingkan pada anak tidak stunting usia 24-59 bulan di desa Muliorejo. Masih tingginya angka stunting di desa Muliorejo perlu segera ditanggulangi secara early warning dengan pemantauan status gizi terutama tinggi badan secara rutin di posyandu sehingga bisa dideteksi dan diberikan intervensi dengan segera.

\section{RUJUKAN}

1. Dieny, Fillah Fihra. 2014. Permasalahan Gizi pada Remaja Putri. Graha Ilmu. Yogyakarta

2. Milman A, Frongillo EA, Onis M, Hwang J. Differential Improvement among Countries in Child Stunting is Associated with Long-Term Development and Specific Interventions. The Journal of Nutrition. 2005 ; 135(2) :1415-1422)

3. Kemenkes, Buletin Jendela dan Data Informasi Kesehatan. 2018. Situasi Balita Pendek (Stunting) di Indonesia. Pusdatin. ISSN 2088-270X, Jakarta, Oktober 2018

4. Kementerian Kesehatan Republik Indonesia. 2018. Situasi balita pendek (stunting) di Indonesia. Jakarta: Pusat 
Data dan Informasi Kementerian Kesehatan Republik Indonesia. 2018.

5. Millennium Challenge Account Indonesia. Backgrounder : Stunting dan masa depan Indonesia. 2014. Diakses tanggal 10 November 2020. Available from www.mca-indonesia.go.id.

6. Kementerian Kesehatan Republik Indonesia. 2018. Laporan Hasil Riset Kesehatan Dasar (Riskesdas) 2018. Badan Litbangkes. Jakarta

7. Profil Kesehatan. 2018. Laporan Riset Kesehatan Dasar. Sumut : Badan Penelitian dan Pengembangan.

8. Ni'mah, Cholifatun dan Lailatul Muniroh. 2016. Hubungan TingkatPendidikan, Tingkat Pengetahuan dan Pola Asuh Ibu DenganWasting dan Stunting Pada Balita Keluarga Miskin. Media Gizi Indonesia, Vol. 10, No. 1.

9. Engle, P. L., Menon, P. and Haddad, L. 1999. Care and Nutrition: Concepts and Measurement. World Development. International Food Policy Research Institute.

10. Rahmayana , Irviani A. Ibrahim , Dwi Santy Damayati. 2014. Hubungan Pola Asuh Ibu Dengan Kejadian Stunting Anak Usia 24-59 Bulan Di Posyandu Asoka II Wilayah Pesisir Kelurahan Ba rombong Kecamatan Tamalate Kota Makassar Tahun 2014. Vol. VI, No. 2, Juli-Desember 2014 ISSN : 2086-2040 Al-Sihah : Public Health Science Journal p. 424-436. UIN Alauddin Makassa

11. Astari, Lita Dwi, dkk. 2015. Hubungan Karakteristik Keluarga, Pola Pengasuhan dan Kejadian Stunting Anak Usia 6-12 Bulan. Media Gizi dan Keluarga, 29 (2): 40-46.

12. Hardianty, Rena. 2019. Hubungan Pola Asuh Ibu Dengan Kejadian Stunting Anak Usia 24-59 Bulan Di Kecamatan Jelbuk Kabupaten Jember. Fakultas Kedokteran Universitas Jember.

13. Febriani Dwi Bella , Nur Alam Fajar, Misnaniarti. Jurnal Gizi Indonesia (The Indonesian Journal of Nutrition) Vol. 8, No. 1, Desember 2019 (31-39) Submitted: 10 Juli 2019, Accepted: 11 Desember 2019, Hubungan pola asuh dengan kejadian stunting balita dari keluarga miskin di Kota Palembang

14. Mega Ade Nugrahmi, Pagdya Haninda Nusantri Rusdi. MIKIA Maternal and
Neonatal Health Journal | November 2020 | Volume 4, Nomor 2 | Hal: 22 28, Pola Asah dan Asuh Berhubungan Dengan Kejadian Stunting di Puskesmas Air Bangis, Pasaman Barat

15. Eka Mustika Yanti, Ns. Ririnisahawitun, Yusma Arisanti .2019. Hubungan Pola Asuh Makan Dan Karakteristik Ibu Dengan Kejadian Stunting Pada Anak Usia 2-5 Tahun Di Desa Marong Lombok Tengah

16. Soetjiningsih \& Ranuh, I.N.G. 2015. Tumbuh Kembang Anak. Edisi 2. Jakarta:EGC

17. Turnip F. 2007. Pengaruh Positive Deviance pada Ibu dari Keluarga Miskin Terhadap Status Gizi Anak Usia 12- 24 bulan di Kecamatan Sidikalang Kabupaten Dairi Tahun 2007 (Thesis). Medan : Universitas Sumatera Utara ; 2008

18. Murtini, Jamaluddin. 2018. FaktorFaktor Yang Berhubungan Dengan Kejadian Stunting Pada Anak Usia 0 36 Bulan. Jikp@Jurnal Ilmiah Kesehatan Pencerah, Volume 7 Nomor 2 Bulan Desember Tahun 2018 \& ISSN:2089-9394

19. Ilya Krisnana, Ika Nur Pratiwi, Adam Cahyadi . 2020. The Relationship between Socio-Economic Factors and Parenting Styles with the Incidence of Stunting in Children 1Faculty of Nursing, Universitas Airlangga, Surabaya, East Java, Indonesia. Sys Rev Pharmacy Vol 11, Issue 5, MayJun $2020: 738-743$

20. Hartono Gunardi, Soedjatmiko Soedjatmiko, dkk. 2017. Association between parental socio-demographic factors and declined linear growth of young children in Jakarta Medical Journal of Indonesia, Vol 26 No 4 (2017): December

21. Komalasari, Esti Suprianti, Riona Sanjaya, Himah Ivayanti. 2020. Faktor Faktro penyebab Stunting pada Balita. Majalah Kesehatan Indonesia. Vol 1 Issue 1.p 52-56. P ISSN 27456498 E ISSN 27458008).

22. Sutarto. Diana Mayasari, Reni Indriarti. 2018. Tinjauan Pustaka. Stunting, Faktor Risiko dan Pencegahannya. J Agromedicine. Ol 5 (1). Juni 2018. P.540-45.)

23. Henny Suzana Mediani. 2020. Global Journal of Health Science; Vol. 12, No. 
8; 2020 ISSN 1916-9736 E-ISSN 1916-9744 Published by Canadian Center of Science and Education 83 Predictors of Stunting Among Children Under Five Year of Age in Indonesia: A Scoping Review 1 Departement of Pediatric Nursing, Faculty of Nursing, Universitas Padjadjaran, Bandung, Indonesia

24. Determinants of Stunted Children in Indonesia: 2020. A Multilevel Analysis at the Individual, Household, and Community Levels Febri Wicaksono*, Titik Harsanti, Kesmas: National Public Health Journal, Wicaksono et al. Kesmas: National Public Health Journal. 2020; 15 (1): 48-53)

25. Bancha Batiro,Tsegaye Demissie, Yoseph Halala, Antehun Alemayehu Anjulo. 2017. Determinants of stunting among children aged 6-59 months at Kindo Didaye woreda, Wolaita Zone, Southern Ethiopia: Unmatched case control study, PLoS One 2017 Dec 20;12(12): e0189106. doi: 10.1371/ journal. pone.0189106. eCollection 2017 Published: December 20, 2017).

26. Bantamen G., Belaynew W., and Dube J. 2014. Assessment of factors associated with malnutrition among under five years age children at Machakel Woreda, Northwest Ethiopia: a case control study. Journal of Nutrition \& Food Sciences, 2014. 4(1): p. 1,View Article, Google Scholar

27. Ayana A.B., Hailemariam T.W., and Melke A.S. 2015. Determinants of acute malnutrition among children aged 6-59 months in Public Hospitals, Oromia region, West Ethiopia: a case- control study. BMC Nutrition, 2015. 1(1): p. 1., View Article.Google Scholar

28. Alemayehu Mussie, et al. Nutritional status and associated factors among under-five children, Tigray, Northern Ethiopia. International Journal

29. Demissie Solomon and Worku A. 2013. Magnitude and Factors Associated with Malnutrition in Children 6-59 Months of Age in Pastoral Community of Dollo Ado District, Somali Region, Ethiopia. Science Journal of Public Health, 2013. 1(4): p. 175-183

30. Ana Paola Campos, PhD, Mireya Vilar-Compte, $\quad \mathrm{PhD}$, and Summer Sherburne Hawkins, PhD 2020. Association Between Breastfeeding and Child Stunting in Mexico. (Ann Glob Health. 2020; 86(1): 145. Published online 2020 Nov 17

31. Loida M García Cruz, Gloria González Azpeitia, Desiderio Reyes Súarez, Alfredo Santana Rodríguez, Juan Francisco Loro Ferrer, Lluis Serra-Majem 2017. Factors Associated with Stunting among Children Aged 0 to 59 Months from the Central Region of Mozambique. Nutrient. 2017 May 12;9(5):491

32. García Cruz LM, González Azpeitia G, Reyes Súarez D, Santana Rodríguez A, Loro Ferrer JF, Serra Majem L. 2017. Factors associated with stunting among children aged 0 to 59 months from the central region of Mozambique. Nutrients. 2017; 9: 1-16. DOI: $10.3390 /$ nu9050491 